\title{
The Unusual Narrator's Threshold Position in the Secret Agent Society of Samuel Beckett's The Unnamable
}

\author{
Mohammadreza Arghiani \\ English Department, Islamic Azad University, Mashhad Branch, Iran \\ Tel: 374-5513-5655_Email:m_r_arghiani@yahoo.com
}

Received: July 26, 2011

doi:10.5539/ells.v1n2p106
Accepted: August 11, 2011

Published: December 1, 2011

URL: http://dx.doi.org/10.5539/ells.v1n2p106

\begin{abstract}
The current study covers topics ranging across The Unnamable's narrative, its unusual narrative methodology, its use of storytelling and sense making, and also in an interdisciplinary manner focuses on post-modern philosophy. It positions The Unnamable's narrative largely at the doorstep of both deconstructive and constructive paradigms and via this approach aims to explore the potential of narrative and narrator in conveying different tacit understandings. This study will be suited for readers because it provides special form of discourse for perceiving the implications of narrator's experience and also textual analysis. In this regard, the study underlines subjects such as unusual narrator's threshold position, narrator's lingual games, predetermined principles and also the concept of panopticon in the Secret Agent Society of the narrative.
\end{abstract}

Keywords: The Unnamable, Narrator, Threshold, Panopticon, Self-orientation, Deconstruction

\section{Introduction}

The Unnamable is the tail entry in Samuel Beckett's Trilogy. What is experienced in this novel seems to be the enigmatic description of incessant talker under the circumstance of investigation and harsh persecution. Unnamablethe title character or the narrator of the story- triggers the narration with breathless dialogic questions and delusional answers: "Where now? Who now? When now? Unquestioning. I say I. Unbelieving. Questions, hypotheses, call them that" (Beckett, 1959, pp. 401). Thus one senses that he is checked up at this point by a power source beyond his control. This peculiar sensation never leaves the readers throughout the narrative; it brings them into a perception about the complexity of Unnamable as a character and sophistication of his style as a narrator from the beginning of narration. As the narrator goes further in his narration, the rate of complexity increases and he uses very multiple voices and very long run-on sentences. He rehearses the several possible voices of the characters such as Basil, Mahood and Worm. These voices can not be easily followed because they intrude to the narration disorderly at any time they like. These restless voices do not have the specific identity and are not actually in search for substantial meaning. They are sometimes so long and misleading that stretch across many pages and in some cases, they even become more complicated than before because of $I$ multiplication and having references to characters from other novels of Trilogy and earlier novels of Murphy, Mercier and Camier, and Watt:

I am neither, I need n't say, Murphy, nor Watt, nor Mercier, nor- no, I can't even bring myself to name them, nor any of the others whose very names I forget, who told me I was they, who I must have tried to be, under duress, or thought of fear, or to avoid acknowledging me, not the slightest connexion. (Beckett, pp. 451)

Such unsettled position of Iness in the narrative expands the distance between teller and told (Moojani, 2008, p. 36) and it confuses The Unnamable's readers. In fact, it creates an ambiguity about who is actually the subject "I". In this regard, the perception of reader (told) is subjective and has the potential to comprehend different meanings, and these meanings mostly differ from that of teller. The ambiguity of the subject and also the bewildered reader's exploration of the subject in the text show the influence of Jacque Derrida's thoughts. In fact, The Unnamable draws attention to process of signification in a closed system of its language. And this endless process leads readers to the study of deconstruction and deconstructive terminologies such as difference and aporia (undeciedability). As Peter Fifield (2008) in Beckett, Contard's syndrome and the Narrative Patient says:

In such cases, the human subjectivity's apparent impossibility gives rise to such suggestions as the Unnamable's narrator being difference writing itself, and/or language's final effacement of illusion of an author figure. Indeed, the coincidence of The Unnamable's disintegrating and self-doubting 
narrative subject with deconstruction's insistence that language functions as an impersonal system of relations of deferral and difference may create the persuasive interpretative stance. Where language precedes and persists beyond the human subject's presence and intention, it is a short interpretive move to excise the subject as site for interpretation. (pp.170)

The study of The Unnamable also continually makes readers ready for tracing Michael Foucault's Panopticon. By deploying certain conventions of interrogation from the pulpy 'secret agent' and crime genres, it describes a panoptic society from the perspective of novel's victim, who serves as the unnamable and unknowable center of a totalizing oppression. In this way, the narrator's creation of (potentially) alternate identities and allusions to previous Beckett novels can be read as an attempt to escape from the constraints of the novel (and the all-seeing eye of the reader) by utilizing the liminal role of the narratorial voice to 'teleport' (for lack of a better word) his agency beyond the limits of societally (and generically) imposed restrictions. However, these attempts actually serve to diminish the little agency the narrator has, so that the more he speaks the more he reduces himself to a shell of a character, present only as a puppet-like embodiment of the panopticon's ability to impose its control through the thought processes of its prisoners without having to expend the usual kinds of power associated with a totalizing force.

The study covers topics ranging across The Unnamable's narrative, its unusual narrative methodology, its use of storytelling and sense making, and also in an interdisciplinary manner focuses on post-modern philosophy. It positions The Unnamable's narrative largely at the doorstep of both deconstructive and constructive paradigms and via this approach aims to explore the potential of narrative and narrator in conveying different tacit understandings. This study will be suited for readers because it provides special form of discourse for perceiving the implications of narrator's experiences and also textual analysis. In this regard, the study underlines subjects such as unusual narrator's threshold position, narrator's lingual games, predetermined principles and also the concept of panopticon in the Secret Agent Society of the narrative.

\section{Discussion}

\subsection{Unusual narrator's threshold position}

All events of the novel are described through the eyes of a narrator who is never named definitely or never identified completely. The narrator is a new phenomenon- a wordless thing or a neutral speech in an empty space, a torso without head, leg and mouth, or a disembodied voice. The narrator is actually an unusual or anti-mimetic kind which is extravagantly incompatible to the world of realism. He uses the first person point of view for the narration and relates one of Mahood's stories but " [his] personal pronoun is an empty signifier; a shifter that does not refer to an exterior reality, but being always available, is filled by whoever utters it”(Pedersen,2004, pp.79).

This permeable narrator slides or collapses into other minds and thoughts for example in opening pages it moves from 'I' pronoun to indefinite pronoun of 'someone' therefore one can not be certain who speaks: "someone says I, unbelieving" (Beckett, pp. 559); or the narrator moves from human like narrator to quasi-human or non-human that reader can not regard him as a definite type of being. In fact, the narrator is an unknown being that has no name, no body and no gender. There is no knowledge that to which world it belongs and also there is no definite answer that he is dead or alive:

There is simply insufficient evidence to establish for sure whether or not death has come indeed an actual event, either of birth or death, would be a comfort, for it would return the unnamable narrator to some definite type of being, even if this is a purgatorial or infernal post-death existence. (Fifield, 2008, p. 180)

This unusual narrator intentionally poses many challenges for readers. He does so firstly to do his role as an unreliable narrator for his meticulous readers perfectly and in the second place to keep his identity as a character secretly under the watchful eyes of his self-proclaimed persecutors. Although he speaks too much, he filters as much as he can about himself: "Yet he can not say anything concrete enough to guarantee existence as anything but a ceaseless and hysterical logorrhea" (Burnett, 2007, pp. 5).

The narrator of The Unnamable intermittently shifts back and forth between the position of (pseudo-) subject and object, author and narrator, narrator and character, the voice of 'I' and the voice of other, named characters, and finally between the position of investigator and investigated. In reality, however, he is none of them, and instead exists in a state of constant flux, a liminal entity only ever on the verge of existence. In his final words the narrator addresses this liminal nature, and locates himself as somewhere suspended at the threshold of narrative embodiment by wondering if his words (or the words of another of which he is only a part): “...have carried me to the threshold of my story, before the door opens on my story, that would surprise me, if it opens, it will be I, it will be the silence, where I am, I don't know, I'll never know, in the silence you don't know, you must go on, I can't go on, I'll go on" 
(Beckett, pp. 407).

This subject of threshold position is one of the most important themes of Jacque Derrida. The narrator uses this issue of suspension many times, and he aims to show that there are undecidable positions in which one can not conform himself to the either side of dichotomies or paradoxes. The narrator remarks that "I'm neither one side nor the other, I' $m$ in the middle, I'm the partition, I've two surfaces and no thickness, perhaps that's what I feel my self vibrating," and he calls himself "the tympanum," considering himself somewhere between "on the one hand the mind, on the other hand the world," but ultimately belonging to neither (Beckett, pp. 376). Thus, "as we have learnt from Derrida's paradoxes, the threshold (the tympanum) is where negation and affirmation meet and coexist" so that the narrator is never able to fully realize himself nor does he ever fully disappear (Nojoumian, 2004, pp. 391).

According to Suzie Gibson (2004), this liminal existence embodies what Maurice Blanchot calls "the neutral," that is, "a resilient yet variable horizon point that allows all forms of expression and endeavour to begin and end," acting "as an endless spindle that unfurls and overturns creation," and in this case, it infinitely unfurls by looping back on itself (pp. 297). This fact, and the quest which results from it, is best summed up by Philip Solomon (1971), when he describes the "mental space" of Beckett's protagonists, noting that "ever since Beckett's first novel, Murphy, whose now famous Sixth Chapter depicted the topography of the mind, the heroes of Beckett's novels have been aware that the essential self is aspatial," something that becomes especially relevant when considering the narrator's quest for an identity (pp. 83-84).

\subsection{Threshold position via lingual games}

It is believed The Unnamable is the unspeakable story of an unnamable practice (intercourse). Its language remains rife with terms like doing it and going at it, and from shame it dares not to reveal the events explicitly. As a result, it offers a series of lingual games in its metaphorical language for description of an unnamable practice. For narrator, characters, words and the text of the story are playing representative roles. It seems that the text represents a female sex organ and characters (Basil, Manhood and Worm) stand for phalluses, and words are like semen spontaneously scattered at every direction and they are containing their own sperms. The narrator (narrative lubricator) penetrates theses characters (phalluses) into the text but none of them can be laid or developed within the feminine text completely. It seems that the text has special virginity and she is defying these characters for tearing her hymen. Since they don't have the power of locating themselves in center of the text, none of these characters can deflower (dismantle) the virginity of the text, they can only stretch it and stand at the threshold of hymen. During the first round of narration (sexual intercourse), the narrator introduces Mahood. Mahood tries to validate his manhood but he suffers from impotency or premature ejaculation. Then he can not tear the hymen and feels insecure about his manhood. In fact, Mahood is the metaphorical barrier between boyhood and manhood. During the second round, the narrator changes the position and uses Worm- a phallic symbol of manhood. Worm seeks to devirginize the text but again it fails. The Unnamable, as a narrator with an over-sized name (big phallus), also wants to tear this hymen but he even can not do so. He can not be in center because he is probably born like Molloy through a hole in his mother's arse and he has not torn the hymen at the birth time.

This array of metaphorical meaning is only the beginning for what suggested about lingual game in the text. Through giving more importance to the text, researcher gradually goes further and proposes more information related to the society of the text. He strongly believes that the text of The Unnamable has an amazing framework. It is not a random collection of words and sentences. The parts that make up it are related in a meaningful way to each other as like as interrelated parts in a normal society in which discipline is a basic requirement. In novel, Unnamable, Mahood and Worm are characters who think beyond the norm of this society. They want to break the rules of the text but the text resist against them. The text indeed wants flabby characters that easily bent or molded in its framework. Character of Worm that is limbless, round shape without mouth, is the indirect embodiment of such submissiveness that the text wants. But the figure of Mahood (anti-Worm) represents the unyielding character who tolerates the harsh harassment or the character who believes in reversal and deconstruction.

Mahood (trapped inside the jar) and Worm (outside of cocoon) are like two poles of a movement: one is strong with interior thoughts and emotions and the other is weak with exteriority. The narrator places himself in a position between these two poles. Surely the separation between these two poles is relative then it is the harmony of Unnamable (Mahood + Worm) which constitutes the unity of narrative world. Unnamable is neither strong nor weak, neither inside nor outside, his "self" is confined at the threshold of the text. He never refuses oppositions such as interiority/exteriority, strength/weakness, present/past, conscious/unconscious, and willingness/obligation. Rather than refusing these oppositions, he tries much to release himself from the discipline and hierarchy of these oppositions and find a name for himself. As the requirement of release, the interior energy of narrator motivates him to attack these principles and on the other hand, his exterior self enforces him to resist. He wants really to be 
creative but former characters formed in his mind like the straitjackets of his mind and his words stop him from having the authority of a name. Then he starts an extreme reproduction or proliferation of "I"s (Mahood, worm, Basil and other names). He presumes the diversity of "I"s for himself but he knows that he is none of them, there are only words that are compulsorily put on his mouth as the text says "only I knew what they want, they want me to be Worm, but I was, I was" or they are like tears that are unintentionally poured in his eyes: "I, of whom I know nothing, I know my eyes[ "I"s] are open, because of tears that pour from ... unceasingly" (Beckett, pp. 505).

According to this proliferation of "I" pronouns, Unnamable on every occasion takes on a new identity and he continually changes this identity from one era to the next. This unbroken succession of $I$ 's and drastic changes of characters reflects Foucault's straitjacket and theory of discontinuity and also reveals the narrator's failure in specifying his voice in the narrative process:

\section{Is there a single word of mine in all I say? No, I have no voice; in this matter I have none. That's one of the reasons why I confused my self with Worm. But I have no reasons either, no reason, I'm like Worm, without voice of reason, I'm Worm, no, if I were Worm I wouldn't know it... Who make me say that I am he perhaps, as they are. Who make me say that since I can't be he I must be he. That since I couldn't be Mahood, as I might have been, I must be worm, as I cannot be. But it is still they who say that when I failed to be Worm I will be Mahood, automatically, on the rebound? (Beckett, p. 481-482)}

The voice of The Unnamable negotiates for its being between self (Ines) and others (Mahood, Worm and etc.) and it demands finality which is never accomplished; it is deferred in the process of signification. This issue associates the failure in Beckett's voice system to Derrida's Difference in the sign system. It means that the voice that one imagines to signify Unnamable is the signifier with which everyone signifies him and there is no final referent or foundation in this process:

The voice in The Unnamable cannot be assigned a fixed spot; sly, slippery, masked, an intriguer, the voice is neither of I nor of "I", but rather a sort of joker, a floating signifier signifying nothing but articulating itself. Neither a representative nor an imitator it merely mimes itself thus putting into play the either/or between I and "I", endlessly re-producing difference. (Balinisteanu, 2003, pp. 172)

\subsection{Self-orientation/Predetermination}

Undoubtedly the narrator used to speak too much but there is a question here that for what reasons he has this habit of talking and what are the causes and effects of this long chattering habit. These questions are significantly complicated and the answers to them are too much difficult because they are mystical rulings and radical permutations behind the narrator's words and thoughts: "I am in words, made of words, other's words, what others...I am all these words, all these strangers, this dust words, with no ground for settling ..." (Beckett, pp. 537).

There is one answer to these questions that underlines the concept of self and the other which revolves around the sovereignty of predetermined principles. It means that narrator firstly speaks too much because he wants to put himself in the center spot and to give authenticity to his self-reported narration, and secondly because there are unknowing potentials that are putting words in his mouth although he is no sure that he has mouth: "I have no opinion, what would I have an opinion with, with my mouth perhaps, if it's mine, I don't feel a mouth on me, if only I could feel something on me, ...” (Beckett, pp. 563).

These answers of self-orientation and preordination are closely bound up with each other and in the study of them, researcher regards the functions of consciousness / unconsciousness because these are necessary aspects in activation of narrator's language and mind. The Unnamable's narrator sometimes uses some hints in supporting that the story is just fabrication of his conscious mind and he says directly that events are "all invented, basely, by me alone with the help of no one" and through this he aims to reveal himself as an unaided narrator and sole power, but it is not so in truth because there are lots of moments that he complains about predetermined principles and past-time memories that are meddling in his narration: "All these Murphys, Molloys and Malones do not fool me. They have made me waste my time, suffer for nothing, speak of them when, in order to stop speaking, I should have spoken of me and of me alone" (Beckett, p. 419). He knows that these concerns are putting him in a position of secondary importance but he can not delete them. These meddling principles and memory models are latent potential sources or unconscious fundamentals in his mind that are set or formed in advanced. He constantly tries to distract his attention away from them but they are very intriguing and very extensively detailed that he can not forget them. Thus, he starts to fluctuate between these two poles of unconsciousness and consciousness as like as a pendulum. This ongoing fluctuation results a self-destructive behavior in which narrator's "self" becomes split to Mahood and Worm. As Federico Bellini (2009) notes in his essay "this withdrawal and retroactive splitting of the subject constitutes the primal imbalance of the narrative plan from which the rest of book will derive its momentum" (pp. $5)$. 
In other words, this new position motivates the narrator's long chattering more and more and at the same time brings him to the world of subconscious in which he alternates between the two stories of Mahood and anti Mahood (Worm). In these alterations, he indirectly suggests that the events which are connected with Mahood are related to consciousness and the story which relates Worm guides to unconsciousness. And also the whole events of The Unnamable (Unnamable $=$ Mahood + Worm) indicates his own sub-consciousness: "The voice, which guides us through The Unnamable, is most often attributed to either Mahood or worm. It is between them that the "I" shifts, in its vain attempt to establish its own identity" (Asja Szafraniec, 2007, pp.128).

\subsection{The Secret Agent Society (SAS)}

In his seminal work Discipline and Punish: The Birth of the Prison, Foucault uses the image of the panopticon to describe the effects of society on the individual. Originally, the panopticon was a kind of prison in which a central observation station was surrounded by prisoners, such that no prisoner could ever be certain as to whether or not he or she was being observed. The panopticon centralizes the space of the observer while simultaneously mystifying the act of observation, such that the threat may be ever-present even if an actual prison guard is not. In the same way, Foucault's conception of the societal panopticon imposes its standards on the individual, who must conform to the standards of society due to a fear of the possibility of discovery and punishment. According to Foucault, "the Panopticon is a privileged place for experiments on men, and for analyzing with complete certainty the transformations that may be obtained from them" (1977, pp. 204). The space the narrator finds himself in at the beginning of The Unnamable functions in this same way, except that in this case the object of the panopticon's gaze has not undergone the process of subjectification prior to finding itself there.

The narrator simply exists upon the reading of the novel, and is subsequently unable to undergo the process of subjectification over the course of the novel because he has already been locked into place as the void of humanity constrained by a society that has so totally permeated everything that it need not ever reveal itself. In a normal formulation of subjecthood (as discussed in psychoanalytic terms), "the parental gaze both assures the infant of its subjective existence and threatens to stare it into submission by its stern surveillance," but in this case, the narrator experiences the stern surveillance without the subjecting gaze (Moorjani, 2008, pp. 44). This is why the only character to ever be 'seen' in the novel is the narrator; just as the prison panopticon gains its power from the assumption of power given to it by the prisoner, so too does the panopticonic society implied by the novel gain its power by the narrator's own enactment of it through his narration. Thus, the narrator's attempt at subjectification by uttering "I say I" fails because there actually is no Other for him to orient his 'I' against, or put another way, there is no one or no thing to call the narrator 'you.' This fact is integral to any understanding of The Unnamable, because it informs the entirety of the subsequent narration, as the narrator attempts again and again to establish a subject for himself, first by inventing additional identities and then by attempting to obtain the role of author by alluding to Beckett's previous works. Thus, having established the necessary critical tools and demonstrating their overarching importance to this analysis of The Unnamable, it will be possible to examine the novel in greater detail to see how this dynamic plays out to its tragic end.

Before considering the narrator's various attempts to establish an identity for himself, it will be useful to address the framework in which these attempts are made. The narrator of the Unnamable is an undercover character who has a secret and keeps that secret from readers and his supposed interrogators throughout the novel. The existence of such undercover character is not a new subject in Beckett's works because there have been a number of such characters for instance Knott, Watt and Moran in Beckett's earlier novels. But it seems that the Unnamable has a particular occasion because it recalls more of these undercover characters not only Molloy or Malone but also Mercier and Camier and Murphy in itself. It is seemingly a display of the Secret Agent Society (SAS) with all trained secret agents alongside the best and most experienced masters including Mahood and Basil. There is also something actually interesting in the narrative, during the story narrator disguises himself to Mahood and Worm and more interestingly that sometimes he even becomes the author whom he has written all these confessions about Unnamable and all other characters on paper. The narrative indeed creates doubt about author, character and narrator in a way that narrator himself says explicitly in a part of narration that "I say aporia without knowing what it means" (Beckett, pp. 402).

The use of both the aporic chattering and multiple points of view provides the narrator a good opportunity to play with his readers as well as with the text. So that he performs the role of an arrested secret agent who resists not revealing anything about his true self. In this way, he practices and reviews the events in a way that one thinks he himself has got some lessons and techniques including the most effective trainings and modern investigative methods of spy world. He says: "They gave me courses on love, on intelligence most precious, most precious. They also taught me to count, and even to reason. Some of this rubbish has come in handy on occasions; I don't deny it, on occasions which would never have arisen if they had left me in peace" (Beckett, pp. 411). 
Narrator engages himself with the conventions of the secret agent genre. And in doing so he uses suspense, tension and excitement as the main elements of his narration. He repetitively employs the exiting themes of investigation, whodunit, mind games, confinement and death traps and by putting himself in the role of an anonymous agent under the torture, gives the highest voltage of thriller to his bewildered readers and joins them to the stirring world of SAS. When the narrator describes SAS, he simultaneously reviews something unconsciously from Moran - from the hero of the second part of Molloy. He exaggerates about events and talks of a new dangerous mission with unknown agent in order to compensate the failure and boredom of Moran's because in the case of Moran, SAS's operation did not have a positive outcome.

Compared to the last two novels of Trilogy, The Unnamable's narrator is very selective and when he comes to the descriptions of Unnamable and his self created SAS, his descriptions are provoking. His comments and descriptions of SAS resemble the Foucauldian models and metaphors of panopticon in which the harsh surveillance operation and intelligent code cracking system are utilized to control the Unnamable's behaviors. In this framework of panopticon, Unnamable is always under careful observation and more importantly that he himself knows about it: “They are watching me from afar, I have no objection, as long as I don't see them, watching me like a face in the embers which they know is doomed to crumble, but it takes too long, it is getting late, eyes are heavy and tomorrow they must rise betimes" (Beckett, pp. 424)

Panoptical society of The Unnamable conducts the harsh surveillance and uses the diversity of physical and mental distresses like sleep preventing, voice cloning, mind abusing and humiliation but Unnamable resists and continually addresses himself for carrying on: "I have nothing to do, that is to say nothing particular. I have to speak, whatever that means. Having nothing to say, no words but words of others, I have to speak" (Beckett, p. 308). And through this endless resistance, he challenges the notions of surveillance and torture and confirms the idea of Foucault that says in the modern and post-modern world, people no longer need humiliation, torture and surveillance by centralized authorities in order to create socially disciplined bodies.

\section{Conclusion}

By examining the narrator's threshold position (Derrida's tympanum) and the binary of self-orientation and predetermination, one is able to see how the predicament of the narrator embodies the role of the citizen in the panopticon as conceptualized by Michel Foucault. The liminal nature of the narrator allows him to transfer his voice to that of different named characters for brief instances, and even go so far as to claim the role of author, but in the end this liminal nature is actually revealed to be the very thing keeping him under the control of his interrogators, and by extension, society. The narrator is trapped by his own narration, and the totalizing domination of the panopticon is demonstrated by the narrator's self-destruction (and cyclical rebirth) that results in his rambling attempts to escape its influence.

In a way the narrator is revealed to be only a constituent part of the panopticon, or totalizing other, and thus is unable to ever achieve a subjecthood of his own. All of his grandstanding about his own narrative authority is a smokescreen, serving to mystify and shroud the total observation of the societal authority by pretending that anything about the narrator's character or predicament is a result of his own agency, which itself is only temporarily granted to him by the more powerful force of the story itself. Thus, the novel reveals the difficulty of escaping the unconscious structures and limitations of society, which remain so pervasive in human thought that even most attempts to subvert these limitations only serve to reinforce them via the destruction of the individual subject. In a way, the novel seems to suggest that the only resistance to the overwhelming constrictions of the Foucauldian panopticon is to abstain from engaging it, to keep quiet, and thus disallow the assimilation of one's voice into the dominating totality of society.

\section{References}

Balinisteanu, Tudor. (2003). Meaning and Significance in Beckett's The Unnamable. Applied Semiotics, 13(2), 167-175. [Online] Available: http://french.chass.utoronto.ca/as-sa/ASSA-No13/Article4en.html (May 30, 2011)

Beckett, Samuel. (1959). Three Novels: Molloy, Malone Dies, The Unnamable. New York: Grove Press.

Bellini, Federico. (2009). Beckett's Ticklish Characters: reading Beckett through Žižek. International Journal of Zizek Studies, 3(3), 1-12

Burnett, Jacob C. (2007). The Satanic Self in Chaucer, Milton, and Beckett. Diss. Raleigh, North Carolina.

Foucault, Michel. (1977). Discipline and punish: the birth of the prison. New York: Knopf Doubleday Publishing Group.

Fifield, Peter. (2008). Beckett, Cotard's Syndrome and the Narrative Patient. Journal of Beckett's studies, 17(1-2), 
169-186. http://dx.doi.org/10.3366/E0309520709000120

Gibson, Suzie. (2004). THE WORK, THE NEUTRAL AND THE UNNAMABLE. Samuel Beckett Today/Aujourd'hui, 14(10), 293-305

Moorjani, Angela (2008). Deictic Projection of the I and Eye in Beckett's Fiction and Film. Journal of Beckett's studies, 17(1-2), 36-51. http://dx.doi.org/10.3366/E0309520709000077

Nojoumian, Amir Ali. (2004). SAMUEL BECKETT'S THE UNNAMABLE: The Story of that Impossible Place Named Silence. Samuel Beckett Today/Aujourd'hui, 14, 388-404

Pedersen, Jacob L. (2004). Enunciation, Subjectivity, and Nutrality-Artistic Experience in Samuel Beckett. Nordisk estetisk tidskrift, (29-30), 76-86

Solomon, Philip Howard. (1971). SAMUEL BECKETT'S L'INNOMMABLE: THE SPACE OF FICTION. Forum for Modern Language Studies, 7(1), 83-91. http://dx.doi.org/10.1093/fmls/VII.1.83

Szafraniec, Asja. (2007). Beckett, Derrida, and the event of literature. Palo Alto: Stanford University Press.

Uhlmann, Anthony. (1997). The same and the other: Beckett's The Unnameable, Derrida and Levinas. Law Text Culture, 3(1), 127-147 